\title{
PHYTOCHEMICAL PROFILE, ANTIOXIDANT AND ANTIPROLIFERATIVE ACTIVITIES OF OLIVE LEAF EXTRACTS FROM AUTOCHTHONOUS TUNISIAN CULTIVARS
}

\author{
H. Essafi ${ }^{\mathrm{a}}$ b*, N. Trabelsi ${ }^{\mathrm{a}}$, C. Benincasa ${ }^{\mathrm{c}}$, A. Tamaalli ${ }^{\mathrm{a}}$, E. Perri ${ }^{\mathrm{c}}$ and M. Zarrouk ${ }^{\mathrm{a}}$ \\ ${ }^{a}$ Laboratory of Biotechnology of Olive, Center of Biotechnology of BorjCedria, BP 901, 2050, Hammam-Lif. \\ Tunisia \\ ${ }^{b}$ University of Tunis El Manar, Faculty of Sciences of Tunis, Campus University, Tunis 1060. Tunisia \\ ${ }^{\mathrm{c}}$ CREA Research Centre for Olive, Citrus and Tree Fruit, C. da Li Rocchi, 87036 Rende (CS). Italy.
}

(Received: 5 January 2019; accepted: 21 February 2019)

\begin{abstract}
The aim of the present study was to investigate the biological activities of Tunisian olive leaf extracts and to correlate these activities to their phytochemical composition. The phenolic profile of four Tunisian autochthonous cultivars Chemlali, Sayali, Neb jmel, and Meski was determined using LC/MS-MS. The antioxidant activity of olive leaf extracts was evaluated using DPPH test. The antiproliferative effect was also investigated using MTT assay. The phytochemical screening showed that phenolic content and phenolic class repartition were significantly affected by olive leaf cultivars. Twenty-one components were identified and oleurpein, luteolin 4-glucoside, luteolin 7-glucoside, and apigenin 7-glucoside were the major phenolic components. Among all extracts, Sayali exhibited the strongest antioxidant and antiproliferative activities $\left(\mathrm{IC}_{50} 41.36 \mu \mathrm{g} \mathrm{ml}^{-1} / \mathrm{EC}_{50} 147.11 \mu \mathrm{g} \mathrm{ml}^{-1}\right)$. The MTT result showed that olive leaf extract reduced MCF-7 cell viability in a dose-dependent manner. Western blot analysis demonstrated that olive leaf extracts exhibited antiproliferative activity through apoptosis induction.
\end{abstract}

Keywords: olive leaves, biological activities, free radical scavenging, antiproliferative activity, apoptosis

Olive leaves represent an abundant and unexploited source of bioactive compounds (TALHAOUI et al., 2018). Indeed, finding new applications for olive leaves is of great value to the economy, to the environment, and to the human health (RoDRIGUES et al., 2015). Several studies have shown that olive leaf exhibit a large number of biological activities including antimicrobial, anti-inflammatory, antioxidant, and anti-carcinogenic activities (SABRY, 2016). All these beneficial effects have been related mainly to the presence of bioactive phenolic compounds. The phenolic composition of olive leaf is quite complex and strongly influenced by several factors, such as geographical origin, extraction procedure, and cultivar (ABAZA et al., 2015).

Recently, there has been great interest in olive leaf as a source of antioxidants, which can significantly delay or prevent oxidation of targeted substrate by scavenging free radicals (KHALIQ et al., 2015). Moreover, olive leaves have shown anticancer effects on various tumor cell lines including breast cancer cells (SAMET et al., 2014). These mentioned health properties have promoted active research on methods to identify and quantify olive leaves extract. In this regard, the aim of this study was to investigate the chemical composition and the biological potentials of Tunisian olive leaf cultivars.

\footnotetext{
* To whom correspondence should be addressed. Phone/fax: +216 71430 934; e-mail: hanen_safi@yahoo.fr
} 


\section{Materials and methods}

\subsection{Sample preparation}

Olive leaves of autochthonous cultivars (Chemlali, Sayali, Neb jmel, and Meski) were collected in mid-March from an olive orchard located in Mahdia (center of Tunisia, 35 30' N, $11^{\circ} 04^{\prime} \mathrm{E}$ ). The climate of this area is moderate. Olive trees were grown under natural rainfall, without application of pesticides. Fresh leaves were dried at room temperature $\left(25^{\circ} \mathrm{C}\right)$, ground to a fine powder, and conserved at $-80^{\circ} \mathrm{C}$ until analysis.

\subsection{Extraction and phenolic analysis}

Phenolic extraction was evaluated according to the procedure described by ABAZA and coworkers (2011). The powdered tissue was added to a mixture of methanol and water (80:20, $\mathrm{v} / \mathrm{v})$. The mixture was extracted in the ultrasonic bath for $15 \mathrm{~min}$ at room temperature and centrifuged at 5000 r.p.m. for $25 \mathrm{~min}$. The filtrates were evaporated in rotary evaporator (Buchi, Switzerland) below $40^{\circ} \mathrm{C}$.

The samples were analysed by an API 4000 Q-Trap mass spectrometer equipped with a HPLC 1200 series system (Agilent Technologies). The LC-MS was operated in the negative ion mode using multiple reaction monitoring. The chromatographic separation of the analytes was achieved by reverse phase chromatography using an Eclipse XDB-C8-A HPLC column ( $5 \mu \mathrm{m}$ particle size, $50 \mathrm{~mm}$ length and $4.6 \mathrm{~mm}$ i.d.). A binary mobile phase was made of $0.1 \%$ aqueous formic acid (A) and methanol (B). The total elution time was 20 min per injection (Ben Mohamed et al., 2018)

\subsection{Determination of the DPPH radical scavenging activity}

The capacity to scavenge the free radical DPPH was monitored according to the method employed by ABAZA and co-workers (2011) with some modifications. Briefly, $0.1 \mathrm{ml}$ of olive leaf extract at different concentrations was added to $3.9 \mathrm{ml}$ of methanolic DPPH solution $\left(6 \times 10^{-5} \mathrm{M}\right)$. The mixture was shaken and left to stand in the dark for $30 \mathrm{~min}$. The radical scavenging activity (\% RSA) was calculated according to the formula:

$$
\% \operatorname{RSA}=[(\text { Abs C-Abs S)/Abs C }] \times 100
$$

where $\mathrm{Abs} \mathrm{C}$ is the absorbance of the control and $\mathrm{Abs} \mathrm{S}$ is the absorbance of the sample

\subsection{Cells culture and treatments}

MCF-7 breast cancer cells obtained from American Type Culture Collection (ATCC) were maintained at $37{ }^{\circ} \mathrm{C}$ in a humidified atmosphere of $95 \%$ air and $5 \% \mathrm{CO}_{2}$. The phenolic extract was dissolved in dimethylsulfoxide (DMSO) at a concentration ranging from $31.25 \mu \mathrm{g} \mathrm{ml}^{-1}$ to $500 \mu \mathrm{g} \mathrm{ml}^{-1}$ and diluted in DMEM/F12 medium supplemented with $1 \%$ DCC-FBS.

\subsection{Assessment of cell viability}

MCF-7 cells were seeded on 48 well plates $\left(0.2 \times 10^{5}\right.$ cells/well $)$ and grown for $24 \mathrm{~h}$ in complete medium. The antiproliferative effect was measured using MTT assay. Seventy-two hours after treatments, fresh MTT was added. After $2 \mathrm{~h}$ incubation, cells were lysed with 200 $\mu 1$ of DMSO. The optical density was measured at $570 \mathrm{~nm}$ in a spectrophotometer. 


\subsection{Western blot analysis}

Blots were incubated overnight at $4{ }^{\circ} \mathrm{C}$ with anti-poly (ADP-ribose) polymerase1 (PARP-1) antibody, anti-cyclin D1. Membranes were stripped and incubated overnight with an antiglyceraldehyde 3-phosphate dehydrogenase antibody, and immune-reactive bands were visualized with the Western blotting detection system (SIRIANNI et al., 2012).

\subsection{Statistical analyses}

ANOVA analysis was used to evaluate the phenolic compounds as function of cultivar. The Tukey's multiple comparisons test was used to compare groups. $\mathrm{P}<0.05$ was considered statistically significant. Pearson's correlation and linear regression were used to evaluate the relationship between phenolic composition/antioxidant activity/growth inhibition of MCF-7 cells.

\section{Results and discussion}

The phenolic extracts of Chemlali, Sayali, Neb jmel, and Meski cultivars were screened for the range of phenolic compounds. All extracts were found to contain high and varying amounts of phenolic compounds. In our study, significant differences were observed for total phenolic contents in extracts. As shown in Table 1, the highest amount was found in Sayali (30.89 $\mathrm{mg} \mathrm{g}^{-1}$ ), while the lowest was registered in Neb jmel extract $\left(23.91 \mathrm{mg} \mathrm{g}^{-1}\right.$ ). Our results reported that olive leaves represent a potential source of phenolic compounds.

In the present study, a total of 21 compounds were identified including oleuropeosides, flavonoids, alcohol phenols, and simple phenols. Quantitatively a difference in the distribution of phenolic compounds and their corresponding groups was observed. The results from ANOVA showed significant quantitative differences in phenolic compounds according to the cultivar $(\mathrm{P}<0.05)$. The obtained result revealed that the phenolic profile of olive leaves is strongly affected by genotype factor. Our results are in accordance with those reported in the literature (Kontominas, 2010; ABAZA et al., 2015).

In all analysed olive leaf cultivars, secoiridoids were by far the main abundant group of phenolic compounds. This dominance of secoiridoids in the phenolic fraction of olive leaves is also reported in the literature (KHALIQ et al., 2015). The main compound in this group was oleuropein. The registered values were $17.68 \mathrm{mg} \mathrm{g}^{-1}$ (Sayali); $15.61 \mathrm{mg} \mathrm{g}^{-1}$ (Chemlali); 14.93 $\mathrm{mg} \mathrm{g}^{-1}$ (Meski), and $11.19 \mathrm{mg} \mathrm{g}^{-1}$ (Neb jmel). Several authors, by the characterization of the phenolic composition of Greek olive leaves (Goulas et al., 2009) and Tunisian olive leaves (TAAmAlli et al., 2012) have observed that oleuropein is the main abundant compound in olive leaves of all cultivars.

Furthermore, our results showed that apigenin-7-O-glucoside was present at concentrations ranging from $0.62 \mathrm{mg} \mathrm{g}^{-1}$ in Sayali extract to $1.40 \mathrm{mg} \mathrm{g}^{-1}$ in Meski extract. Apigenin and luteolin were detected in all samples analysed. Luteolin was found in mean concentration ranging from $0.22 \mathrm{mg} \mathrm{g}^{-1}$ (Sayali) to $1.11 \mathrm{mg} \mathrm{g}^{-1}$ (Meski). These results are similar to those reported by several authors. MEIRINHos and co-workers (2005) have reported luteolin-diglucoside and luteolin 4-O-glucoside the most frequent flavonoids in Portuguese olive cultivars. Diosmetin was detected and quantified in all cultivars. The concentration of tyrosol ranged from $0.041 \mathrm{mg} \mathrm{g}^{-1}$ in Chemlali to $0.33 \mathrm{mg} \mathrm{g}^{-1}$ in Sayali cultivars. The amounts 
of hydroxytyrosol varied from 0.92 to $2.10 \mathrm{mg} \mathrm{g}^{-1}$ for Chemlali and Sayali cultivars, respectively. The concentration of hydroxytyrosol glucoside in Meski was the highest among all cultivars.

Table 1. Quantification of individual phenolic compounds in the leaves of different cultivars

\begin{tabular}{|c|c|c|c|c|}
\hline $\begin{array}{l}\text { Phenolic compound (mg of analyte/g dry } \\
\text { matter) }\end{array}$ & Chemlali & Sayali & Neb jmel & Meski \\
\hline Hydroxytyrosol glucoside & $0.077^{\mathrm{a}} \pm 0.001$ & $0.107^{\mathrm{a}} \pm 0.002$ & $0.444^{\mathrm{b}} \pm 0.010$ & $0.599^{c} \pm 0.040$ \\
\hline Tyrosol & $0.041^{\mathrm{a}} \pm 0.001$ & $0.330^{\mathrm{d}} \pm 0.001$ & $0.252^{\mathrm{c}} \pm 0.005$ & $0.211^{\mathrm{b}} \pm 0.002$ \\
\hline Vanillin & $0.659^{\mathrm{b}} \pm 0.003$ & $1.228^{\mathrm{c}} \pm 0.002$ & $0.600^{\mathrm{a}} \pm 0.001$ & $0.613^{\mathrm{a}} \pm 0.007$ \\
\hline Hydroxytyrosol & $0.924^{\mathrm{a}} \pm 0.001$ & $2.101^{\mathrm{c}} \pm 0.012$ & $0.941^{\mathrm{a}} \pm 0.003$ & $1.152^{\mathrm{b}} \pm 0.032$ \\
\hline Rutin & $0.820^{\mathrm{d}} \pm 0.002$ & $0.605^{\mathrm{c}} \pm 0.001$ & $0.431^{\mathrm{b}} \pm 0.003$ & $0.243^{\mathrm{a}} \pm 0.004$ \\
\hline Apigenin & $1.218^{\mathrm{b}} \pm 0.008$ & $0.914^{\mathrm{a}} \pm 0.005$ & $1.308^{\mathrm{b}} \pm 0.003$ & $1.503^{\mathrm{c}} \pm 0.047$ \\
\hline Luteolin & $0.561^{\mathrm{c}} \pm 0.006$ & $0.226^{\mathrm{b}} \pm 0.002$ & $0.113^{\mathrm{a}} \pm 0.001$ & $1.106^{\mathrm{d}} \pm 0.024$ \\
\hline Diosmetin & $1.137^{\mathrm{d}} \pm 0.009$ & $1.463^{\mathrm{b}} \pm 0.012$ & $0.661^{\mathrm{c}} \pm 0.002$ & $1.162^{\mathrm{a}} \pm 0.004$ \\
\hline Apigenin-7 glucoside & $0.924^{\mathrm{b}} \pm 0.001$ & $0.619^{\mathrm{c}} \pm 0.010$ & $1.153^{\mathrm{a}} \pm 0.001$ & $1.402^{\mathrm{b}} \pm 0.003$ \\
\hline Luteolin -7 glucoside & $2.647^{\mathrm{b}} \pm 0.002$ & $0.978^{\mathrm{c}} \pm 0.003$ & $1.374^{\mathrm{a}} \pm 0.002$ & $1.692^{\mathrm{b}} \pm 0.034$ \\
\hline Luteolin-4 glucoside & $1.709^{c} \pm 0.004$ & $0.777^{\mathrm{d}} \pm 0.004$ & $1.262^{\mathrm{a}} \pm 0.004$ & $1.482^{\mathrm{b}} \pm 0.010$ \\
\hline Oleuropein & $15.609^{\mathrm{b}} \pm 0.111$ & $17.684^{\mathrm{c}} \pm 0.133$ & $11.194^{\mathrm{a}} \pm 0.078$ & $14.913^{\mathrm{b}} \pm 0.331$ \\
\hline Verbascoside & $0.714^{\mathrm{c}} \pm 0.008$ & $1.594^{\mathrm{b}} \pm 0.003$ & $1.224^{\mathrm{d}} \pm 0.012$ & $1.295^{\mathrm{a}} \pm 0.004$ \\
\hline 2"-methoxyoleuropein & $1.005^{\mathrm{d}} \pm 0.004$ & $0.457^{\mathrm{c}} \pm 0.002$ & $0.234^{\mathrm{b}} \pm 0.002$ & $0.115^{\mathrm{a}} \pm 0.004$ \\
\hline Ligostride & $0.290^{\mathrm{a}} \pm 0.000$ & $0.848^{\mathrm{c}} \pm 0.026$ & $0.500^{\mathrm{b}} \pm 0.001$ & $0.329^{\mathrm{a}} \pm 0.008$ \\
\hline Oleuropein aglycone & $0.310^{\mathrm{a}} \pm 0.005$ & $0.394^{\mathrm{b}} \pm 0.002$ & $1.743^{\mathrm{c}} \pm 0.010$ & $0.405^{\mathrm{b}} \pm 0.004$ \\
\hline Aglycon oleuropein dialdehydic & $0.031^{\mathrm{b}} \pm 0.01$ & $0.020^{\mathrm{a}} \pm 0.02$ & $0.066^{\mathrm{c}} \pm 0.001$ & $0.016^{\mathrm{a}} \pm 0.002$ \\
\hline Olpeuropein derives & nd & nd & $0.102^{\mathrm{b}} \pm 0.003$ & $0.017^{\mathrm{a}} \pm 0.001$ \\
\hline Ligastroside aglycone & $0.096^{\mathrm{a}} \pm 0.003$ & $0.306^{\mathrm{d}_{ \pm}} \pm 0.003$ & $0.178^{c} \pm 0.004$ & $0.127^{\mathrm{b}} \pm 0.002$ \\
\hline 10-hydroxy oleuropein aglycon & $0.009^{\mathrm{a}} \pm 0.000$ & $0.030^{\mathrm{c}} \pm 0.001$ & $0.013^{\mathrm{b}} \pm 0.001$ & $0.033^{\mathrm{c}} \pm 0.002$ \\
\hline Hydroxy D-oleuropein aglycon & $0.048^{\mathrm{d}} \pm 0.000$ & $0.025^{\mathrm{b}} \pm 0.001$ & $0.016^{\mathrm{a}} \pm 0.000$ & $0.030^{\mathrm{c}} \pm 0.001$ \\
\hline Total phenols & $29.026^{\mathrm{c}} \pm 0.120$ & $30.898^{\mathrm{d}} \pm 0.164$ & $23.917^{\mathrm{a}} \pm 0.082$ & $28.992^{\mathrm{b}} \pm 0.360$ \\
\hline
\end{tabular}

Results are expressed as mean \pm standard deviation; significant differences in the same row are showed by different letters $(\mathrm{P}<0.05)$; nd: not detected

The obtained results revealed that Sayali extract showed the highest antioxidant potential $\left(\mathrm{IC}_{50}\right.$ value $\left.41.56 \mu \mathrm{g} \mathrm{ml}^{-1}\right)$. Moreover, all olive leaf extracts were able to scavenge free radicals. These results were in agreement with the report by SALAH and co-workers (2012), who showed that olive leaf extracts present a potent antioxidant activity.

Moreover, all extracts induced the decrease of MCF-7 growth in a dose-dependent manner (Fig. 1). As shown in Table 2, olive leaf extracts from Sayali have shown the highest inhibitory effect against MCF-7 cells with a $\mathrm{CE}_{50}$ of $196 \mu \mathrm{g} \mathrm{ml}^{-1}$, followed by Neb jmel, 
Chemlali, and Meski. These results are in agreement with findings of $\mathrm{Fu}$ and co-workers (2010). The authors have estimated the $\mathrm{CE}_{50}$ values of olive leaves ranging from 200 to 300 $\mu \mathrm{g} \mathrm{ml} l^{-1}$.

Table 2. Antioxidant and antiproliferative activities of various extracts of the Tunisian olive leaf cultivars by DPPH and MTT assays

\begin{tabular}{lcc}
\hline Olive leaf extract & $\mathrm{DPPH}\left(\mathrm{IC}_{50}\right) \mu \mathrm{g} \mathrm{ml}^{-1}$ & MTT Test $\left(\mathrm{CE}_{50}\right) \mu \mathrm{g} \mathrm{ml}^{-1}$ \\
\hline Chemlali & $50.17 \pm 1.28$ & $213.05 \pm 2.13$ \\
Sayali & $41.56 \pm 0.41$ & $147.77 \pm 2.78$ \\
Neb jmel & $58.16 \pm 1.21$ & $183.61 \pm 1.07$ \\
Meski & $63.52 \pm 0.47$ & $280.07 \pm 2.55$ \\
\hline
\end{tabular}

The results were given as half maximum effective concentration $\left(\mathrm{IC}_{50}\right.$ and $\left.\mathrm{CE}_{50}\right) ; \mathrm{IC}_{50}$ and $\mathrm{CE}_{50}$ values represent the means \pm standard deviation of three replications $(\mathrm{P}<0.05)$.

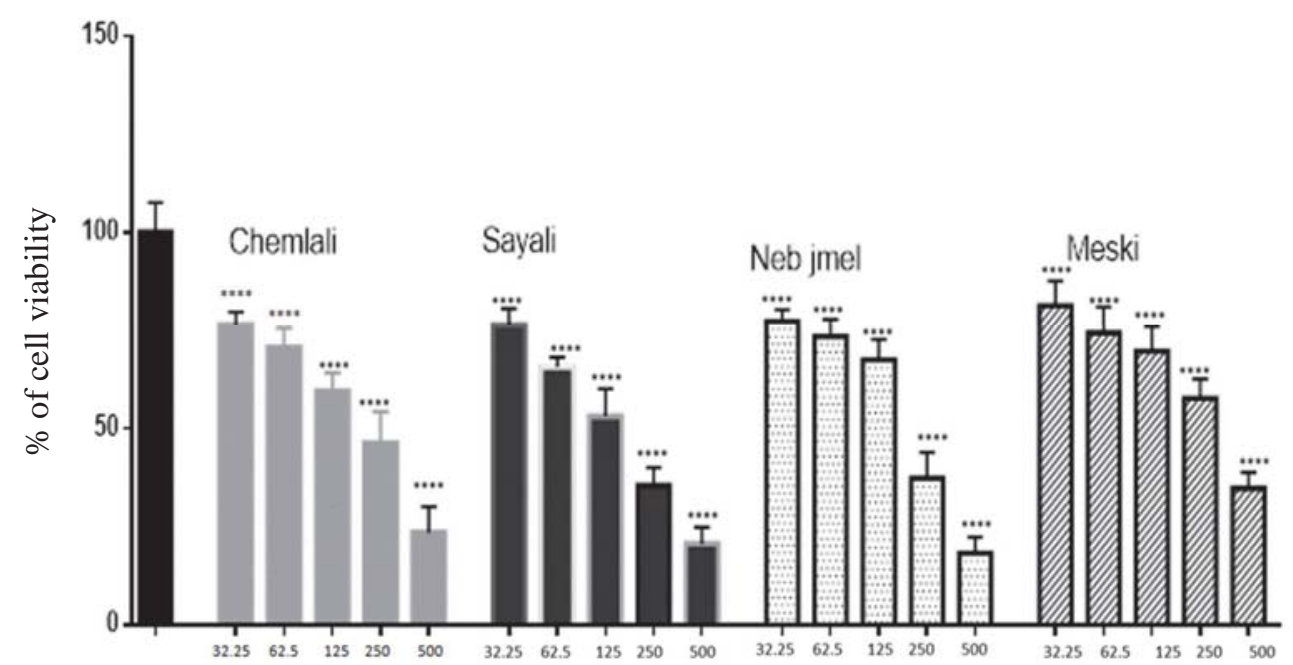

Fig. 1. Effects of different concentration of olive leaf extracts (Chemlali, Sayali, Neb jmel, and Meski) on MCF-7 cell proliferation

Columns are means of three independent experiments each performed with triplicate samples expressed as percent of basal, bars: $\mathrm{SD} ;{ }^{\mathrm{xxxx}}$ : significant difference at $\mathrm{P}<0.0001$ compared with basal

Western blotting analysis (Fig. 2) revealed the presence of cleaved form of PARP-1 in MCF-7 treated cells. Our result demonstrated that olive leaf extracts induce a slightly upregulated expression of cyclin D1 in treated MCF-7 cells when compared to control cells. The obtained result showed that treatment of MCF-7 cells with olive leaf extracts stimulated the apoptosis efficiently.

As shown in Table 3, a positive linear correlation between the antioxidant capacity values $\left(\mathrm{IC}_{50}\right)$ and total phenol content was found. The antioxidant activity of olive leaf extracts could be attributed to their high amounts of total phenol $\left(\mathrm{R}^{2}=0.911\right)$ and total secoiridoids $\left(\mathrm{R}^{2}=-0.975\right)$. Moreover, antioxidant activity could be attributed to the higher oleuropein amount $\left(\mathrm{R}^{2}=-0.964\right)$, as well. 


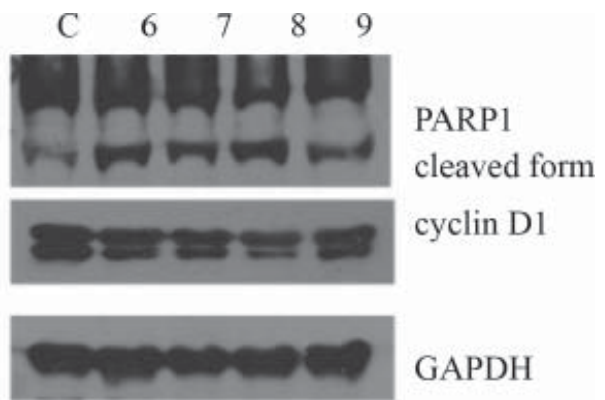

Fig. 2. Effects of olive leaf phenolic extracts on PARP-1 and cyclin D1 activation. Blots are representative of three independent experiments with similar results. (C: Basel; 6: Chemlali; 7: Sayali; 8: Neb jmel; 9: Meski; GAPDH: glyceraldehyde 3-phosphate dehydrogenase antibody)

Table 3. Pearson correlations

\begin{tabular}{|c|c|c|}
\hline Pearson correlations & $\mathrm{IC}_{50}$ & $\mathrm{CE}_{50}$ \\
\hline Vanillin & $-0.862^{* *}$ & $-0.685^{*}$ \\
\hline Hydroxytyrosl & $-0.863^{* *}$ & -0.549 \\
\hline Apigenin & $0.668^{*}$ & $0.876^{* *}$ \\
\hline Luteolin & -0.073 & $0.935^{* *}$ \\
\hline Diosmetin & $-0.810^{* *}$ & 0.235 \\
\hline Apg-7-GLUC & $0.673^{*}$ & $0.850^{* *}$ \\
\hline Lut-4-GLUC & .522 & $0.709^{* *}$ \\
\hline Oleuropein & $-0.964^{* *}$ & -0.151 \\
\hline Ligostride & $-0.578^{*}$ & $-0.798^{* *}$ \\
\hline Oleuropein aglycone & $0.780^{* *}$ & -0.270 \\
\hline Aglyconolpdialde & $0.805^{* *}$ & -0.335 \\
\hline Olpeuropein derives & $0.834^{* *}$ & -0.145 \\
\hline Ligastroside aglycone & $-0.589^{*}$ & $-0.756^{* *}$ \\
\hline Total phenols & $-0.911^{* *}$ & 0.036 \\
\hline Simple phenols & $-0.877^{* *}$ & -0.554 \\
\hline Secoiridoids & $-0.975^{* *}$ & -0.428 \\
\hline Flavonoids & 0.200 & $0.820^{* *}$ \\
\hline
\end{tabular}

$*: \mathrm{P}<0.05 ; * *: \mathrm{P}<0.01$

From this study, it was shown that phenolic compounds largely contribute to the antioxidant activities of olive leaf. Our results are in agreement with those reported in the literature. BENAVENTE-GARCíA and co-workers (2000) reported that the radical scavenging potential of olive leaf extract depends mainly on its amount of phenolic compounds. On the other hand, the obtained results of correlation of phenolic content and $\mathrm{CE}_{50}$ have shown that the anti-proliferative effect in MCF-7 breast cancer cells does not correlate with phenolic content or with antioxidant capacity. 


\section{Conclusions}

The results reveal the richness of Tunisian olive leaves in phenolic compounds. Furthermore, phenolic profile could be used as a fingerprint to discriminate olive leaves by cultivar.

On the other hand, the obtained results showed that Sayali extract exhibited the strongest antioxidant and antiproliferative potentials. In the light of these findings, Sayali extract could be recommended as a source of antioxidant components for therapeutic industries.

\section{References}

Abaza, L., Ben Youssef, N., Manai, H., Mahjoub Haddada, F., Methenni, K. \& Zarrouk, M. (2011): Chétoui olive leaf extracts: Influence of the solvent type on phenolics and antioxidant activities. Grasas Aceites, 62, 96-104.

Abaza, L., Taamalli, A., Nsir, H. \& Zarrouk, M. (2015): Olive tree (Olea europeae L.) leaves: importance and advances in the analysis of phenolic compounds. Antioxidants (Basel), 4, 682-698.

Ben Mohamed, M., Guasmi, F., Ben, S., Radhouani, F., Faghim, J., ... \& Benincasa, C. (2018): The LC-MS/MS characterization of phenolic compounds in leaves allows classifying olive cultivars grown in South Tunisia. Biochem. Syst. Ecol., 78, 84-90.

Benavente-García, O., Castillo, J., Lorente, J., Ortuño, A. \& Del Rio, J.A. (2000): Antioxidant activity of phenolics extracted from Olea europaea L. leaves. Food Chem., 68, 457-462.

Fu, S., Arráez-Roman, D., Segura-Carretero, A., Menéndez, J.A., Menéndez-Gutiérrez, M.P., ... \& FernándezGutiÉrREZ, A. (2010): Qualitative screening of phenolic compounds in olive leaf extracts by hyphenated liquid chromatography and preliminary evaluation of cytotoxic activity against human breast cancer cells. Anal. Bioanal. Chem., 397, 643-654.

Goulas, V., Vassiliki, E., Anastassios, N., Troganis, E.P., Fotsis, T. \& Gerothanassis, E.B. (2009): Phytochemicals in olive-leaf extract and their antiproliferative activity against cancer and endothelial cells. Mol. Nutr. Food Res., 53, 600-608.

Khaliq, A., Sabir, S.M., Ahmad, S.D., Boligon, A.A., Athayde, M.L., .. \& Khan, A. (2015): Antioxidant activities and phenolic composition of olive (Olea europaea) leaves. J. Appl. Bot. Food Qual., 21, 16-21.

Kontominas, M. (2010): Composition and antioxidant activity of olive leaf extracts from greek olive cultivars. $J$. Am. Oil Chem. Soc., 87, 369-376.

Meirinhos, J., Silva, B.M., Valentão, P., Seabra, R.M., Pereira, J.A., ... \& Ferreres, F. (2005): Analysis and quantification of flavonoidic compounds from Portuguese olive (Olea europaea L.) leaf cultivars. Nat. Prod. Res., 19, 189-195.

Rodrigues, F., Pimentel, F.B. \& Oliveira, M. (2015): Olive by-products: Challenge application in cosmetic industry. Ind. Crop. Prod., 70, 116-124.

SABry, O. (2016): Beneficial health effects of olive leaves extracts. J. Nat. Sci. Res., 4, 1-9.

Salah, M., Ben AbdelmeleK, H. \& Abderraba, M. (2012): Study of phenolic composition and biological activities assessment of olive leaves from different varieties grown in Tunisia. Med. Chem., 2, 107-111.

SAmet, I., Han, J., Jlaiel, L., SAYAdI, S. \& Isoda, H. (2014): Olive (Olea europaea) leaf extract induces apoptosis and monocyte/macrophage differentiation in human chronic myelogenous leukemia K562 cells : Insight into the underlying mechanism. Oxid. Med. Cell. Longev. 2014, 1-16

Sirianni, R., Capparelli, C., Chimento, A., Panza, S., Catalano, S., ... \& Andò, S. (2012): Molecular and cellular endocrinology nandrolone and stanozolol upregulate aromatase expression and further increase IGF-Idependent effects on MCF-7 breast cancer cell proliferation. Mol. Cell. Endocrinol., 363, 100-110

Talhaoui, N., Trabelsi, N., Taamalli, A. \& Verardo, V. (2018): Olea europaea as potential source of bioactive compounds for diseases prevention. -in: AtTA-ur Rahman (Ed.): Studies in Natural Products Chemistry, 57, Elsevier, pp. 389-411.

Taamalli, A., Arráez-Román, D., Zarrouk, M., Valverde, J., Segura-Carretero, A. \& Fernández-Gutiérrez, A. (2012): The occurrence and bioactivity of polyphenols in Tunisian olive products and by-products. J. Food Sci., 77, 1-11. 